\title{
Recovery and Reduction of Non-Performing Loans - Podgorica Approach
}

\begin{abstract}
Loan portfolio of Montenegro's banking sector was largely affected by the growth in past due loans during the current financial crisis. High level of these loans limits banks' lending activity which results in a decline in credit supply. Negative effects of the non-performing loans' growth reflected adversely on economic strength of the real and households sectors. Majority of Montenegrin companies have significant liquidity problems and their defaults affect adversely the sound part of the economy, while reduced households spending reflects negatively on aggregate demand.
\end{abstract}

Therefore, a new approach for the recovery of these loans should be sought and reduce their negative impact on loan portfolio of the banking sector. The World Bank Financial Sector Advisory Centre (FinSac) located in Vienna proposed a series of measures and recommendations for the resolution of these loans through several modules. In addition to the strengthening of loan portfolio and initiating more dynamic lending activity of the banking sector, the project called Podgorica Approach aims at strengthening financial stability of the system, supporting debtors' recovery, and improving economic growth.

Podgorica Approach contributed, in particular, to quantitative assessment of the recovery of non-performing loans which could return to the performing status through the restructuring process. Better qualitative understanding of these loans is necessary to act preventively and thus largely reduce migration from performing to non-performing loans. In addition, this approach aims at strengthening the incentives proposed by the authorities so that the level of non-performing loans is reduced through their successful implementation.

Key words: Podgorica Approach, non-performing loans (NPLs), restructured loans, debt restructuring, incentives, financial stability of the system, debtors' recovery, economic growth.

JEL Classification: G01; C25; C11 


\section{Introduction}

The financial crisis was recognised relatively fast in most SEE countries and also in Montenegro owing to the fact that banks are the most supervised and regulated institutions in the economic and financial systems of these countries. This task has been facilitated by the banking regulations that require ongoing monitoring of the banking operations and vulnerability of the loan portfolio that could be exposed to adverse events such as non-performing loans (NPL) growth. Decision on Minimum Standards for Credit Risk Management in Banks prescribes that non-performing loans (NPLs) are those classified into the classification categories "C", "D" and "E" by the bank applying the criteria for asset classification under this Decision.

Financial systems are pro-cyclical in most of the global economies. This is also the case with the Montenegrin financial system. Banking loans influence GDP growth in the expansion stage, which directly affects an increase in procyclicity. During an economic boom, profit of the banking and real sectors increases, as well as income of the population due to the growing exposure to the real and households sectors. However, in recession, procyclicity deteriorates the cycles. Negative cycles generate a crisis, which is demonstrated in the banking sector as a lower exposure to the real and households sectors. Thus, GDP declines, as well as banks' and real sector's profit, and the households sector faces numerous problems. Therefore, economic contraction threatens the banking sector's stability.

The financial crisis which resulted in economic downturn after a strong economic growth left numerous past due loans in the balance sheets of Montenegrin banks which have induced uncertainty and poor ability of banks to continue with a higher volume of lending. The crisis effects have reflected in deterioration of operating indicators of the majority of banks. Banks' assets and capital declined. Over-indebtedness of the real and households sectors which reflects through high percentage of non-performing loans prevents more dynamic banking activity. This results in adverse classification structure of loans.

Based on the Decision on Minimum Standards for Credit Risk Management in Banks, banks are obliged to classify asset items into one of the following classification categories, depending on the given default (Table 1). 
Table 1: Classification of assets for credit risk management

\begin{tabular}{ccccc}
\hline $\begin{array}{c}\text { Classification } \\
\text { category }\end{array}$ & Past due days & Provisioning & Asset characteristics \\
\hline A & $0-30$ days & $0 \%$ & Pass \\
\hline B & $31-90$ days & $2 \%-7 \%$ & Special mention \\
\hline NPL & C & $91-270$ days & $20 \%-40 \%$ & Substandard \\
& D & $271-365$ days & $70 \%$ & Doubtful \\
\hline E & 366 and over & $100 \%$ & Loss \\
\hline
\end{tabular}

Source: Central Bank of Montenegro (CBCG)

Loan portfolio of Montenegrin banks deteriorated under negative effects of the crisis and the level of past due loans and toxic assets increase (transition from A and $\mathrm{B}$ classification categories to non-performing categories $\mathrm{C}$ and $\mathrm{D}$ ). In addition, written off loans substantially grew due to inability of their regular servicing (classification category E).

This paper is aims to contribute to efficient management of voluntary debt restructuring of the economically viable companies in Montenegro. A special contribution of this paper reflects in overall mapping of the recovery or enforced resolution of past due loans. The paper proposes objectives and specific measures for voluntary financial and corporate debt restructuring, and the improvement of implementation of this process.

The paper introduction is followed by three chapters and ends with concluding remarks. The first chapter presents all relevant data referring to the past due loans growth and their relation to non-performing and total restructured loans in the Montenegrin banking sector during the recent financial crisis. The second chapter gives the basics and the objective of voluntary debt restructuring, implementation of measures for financial and corporate restructuring, and indicators obtained based on the assessment (mapping) of the loan portfolio of the banking sector of Montenegro. The third chapter display the process implementation. Legal regulation of voluntary debt restructuring is highlighted, as well as the establishment of the Centre for Mediation with the Arbitration Council and their competences.

\section{Data Availability and Relevance}

Important indicator of the financial crisis in economic theory and practice is when the NPL ratio in the banking system exceeds 10\% (Goldstein \& Weath- 
erstone 2001, pg. 23-24). According to the available data, NPLs' growth during 2009 coupled with a plunge in deposits were early warning indicators of a crisis in Montenegro's banking system. Deficiencies of data transparency in the previous period and likelihood of reporting smaller share of NPLs in the balance sheets of some banks pointed to the fact that the problem is even higher. In the middle of 2011, NPLs reached their peak of nearly $26 \%$. In the second half of the year, with a substantial support of parent banks, a programme for removing NPLs from the balance sheets of banks was performed and they declined to $15 \%$. However, they grew again in the following years.

The growth in NPLs influences significantly credit supply. Due to the psychological effect, banks are reluctant to extend new loans when they see that old loans are in default. Moreover, NPLs influence a decline in loans due to growing financing costs, interest margin growth, and reduction in free capital.

Financing costs imply provisioning needed to cover final loan losses. Uncertainty with regard to potential losses grows as NPLs grow. The bigger the uncertainty the higher the risk premiums for potential losses. As risk premiums increase, available funds for borrowers' funding decrease by the same amount (Diawan \& Rodrik,1992). A decline in credit supply comes as a result of such situation. This is presented in Table 2 where we can see a decline in total loans as of 2009.

Table 2: Loan portfolio of Montenegro's banking sector (in thousands $€$ )

\begin{tabular}{|c|c|c|c|c|c|c|c|}
\hline Year & $\begin{array}{l}\text { Total } \\
\text { loans }\end{array}$ & $\begin{array}{c}\text { Non- } \\
\text { performing } \\
\text { loans (NPL) }\end{array}$ & $\%$ & $\begin{array}{c}\text { Aggregate } \\
\text { past due } \\
\text { loans }\end{array}$ & $\%$ & $\begin{array}{l}\text { Restructured } \\
\text { loans }\end{array}$ & $\%$ \\
\hline 2007 & $2,245,600$ & 70,900 & $3 \%$ & 83,200 & $4 \%$ & - & - \\
\hline 2008 & $2,797,500$ & 201,300 & $7 \%$ & 321,500 & $11 \%$ & - & - \\
\hline 2009 & $2,397,700$ & 324,200 & $13 \%$ & 548,000 & $23 \%$ & 203,100 & $8 \%$ \\
\hline 2010 & $2,199,900$ & 461,300 & $21 \%$ & 522,400 & $24 \%$ & 295,100 & $13 \%$ \\
\hline 2011 & $1,955,700$ & 303,700 & $15 \%$ & 377,900 & $19 \%$ & 277,300 & $14 \%$ \\
\hline 2012 & $1,862,500$ & 327,800 & $18 \%$ & 443,800 & $24 \%$ & 312,700 & $17 \%$ \\
\hline $2013^{* *}$ & ${ }^{*} 2,241,300$ & 448,700 & $18 \%$ & 501,200 & $21 \%$ & 432,100 & $17 \%$ \\
\hline
\end{tabular}

Source: CBCG

* Pursuant to the new regulation that has been effective since January 2013, the category of loans has been significantly expanded i.e. loans cover several balance sheet positions compared to the previous period. The amount of loans for 2013 was presented on net principle (in accordance with the IAS requirements,) while asset quality indicators are shown on gross principle (according to the determined methodology).

** Total gross loans amounted to $2,441,338$ (in thousands $€$ ) 
The growth in non-performing loans influences the interest margin growth. Therefore, banks must cover costs of managing non-performing loans from interest margin (Mohd, 2010). Thus, lending interest rates indicate growth trend and they are substantially higher than deposit interest rates, which was also the case of Montenegrin banking sector (Graph I). Although it is difficult to determine it empirically, some banks try to compensate a portion of loan losses by increasing interest margin. In both cases, lending interest rates will grow and credit supply will decline.
Figure 1: Weighted average lending and deposit effective interest rates in \%

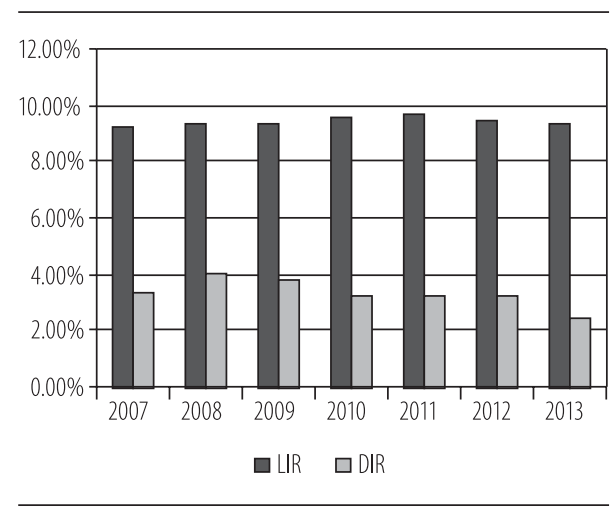

Source: CBCG

Banks' capital declines as non-performing loans grow. Lower capitalization reduces banks' capacity for lending (Demirgüç -Kunt, Detragiache \& Gupta, 2000). If the banks are not immediately recapitalised or if they do not have excess of capital, credit supply will be affected. Montenegrin banking sector was recapitalized in 2011 by the intervention of parent banks and concurrent "cleaning" of toxic assets. Eleven banks operate in Montenegro. Nine of them are majority owned by foreign banks or banking groups, and 2 banks are majority domestic owned.

Past due loans are also those included in better assets of the loan portfolio "B" (Table 3). Loan loss provisions should be also allocated for this credit risk category. Thus, past due loans (B, C and D) reached $23 \%$ of the total loan portfolio of the banking sector in Montenegro during 2009. They continued to grow in the following years (except in 2011 when they declined due to the "cleaning" of the balance sheets).

Table 3: Loans by classification categories, (in thousands $€$ )

\begin{tabular}{ccccc}
\hline Year & $\begin{array}{c}31 \text {-90 days past } \\
\text { due loans }\end{array}$ & $\begin{array}{c}91 \text { - 270 days past } \\
\text { due loans }\end{array}$ & $\begin{array}{c}271-365 \text { days past } \\
\text { due loans }\end{array}$ & Loss over 366 days \\
\hline 2009 & "B" & "C" & "D" & "E" \\
\hline 2010 & 323,700 & 116,600 & 107,700 & 99,800 \\
\hline 2011 & 282,000 & 172,100 & 68,400 & 220,800 \\
\hline 2012 & 226,300 & 105,500 & 46,200 & 152,100 \\
\hline 2013 & 226,200 & 157,800 & 59,900 & 110,100 \\
\hline & 156,800 & 111,800 & 50,200 & 182,400 \\
\hline
\end{tabular}


Figure 2: Problem loans trend, (in thousands $€$ )

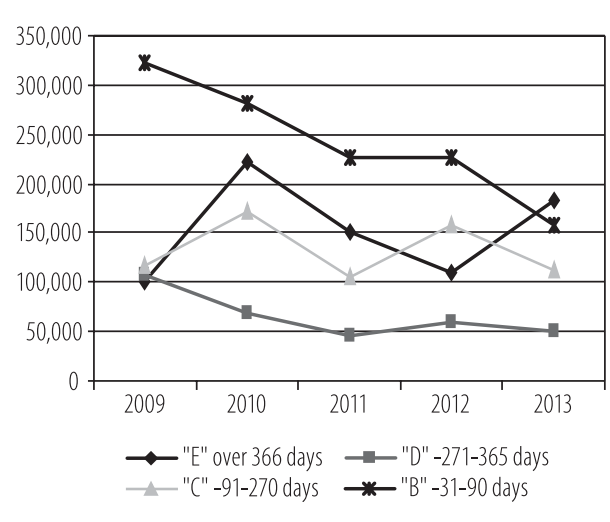

Source: Author

Figure 3: Restructured, non-performing and past due loans, (in thousands $€$ )

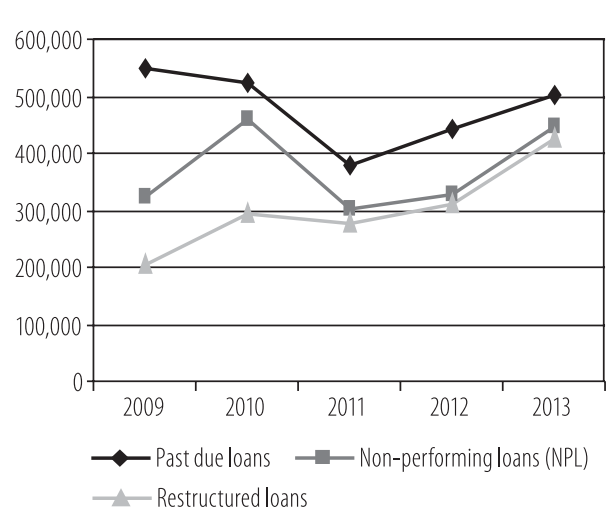

Source: Author
Seriously faced with this problem during 2009, banks started to resolve nonperforming loans more intensively by applying some of the already known measures of debt restructuring. The most commonly used measure by banks was loan rescheduling (modification of the maturity date), and rarely the changing of interest rates (write off of default interest rate) or reduction of debt principal. Figure 3 shows that this activity gave some results because restructured loans almost reached the level of NPLs. Thus, it could be concluded that the problem was resolved and the loan portfolio of the banking sector of Montenegro was fully strengthened.

However, despite the restructuring measures taken by banks, aggregate non-performing loans were on their uptrend (Figure 3). During 2013, they reached higher level compared to 2011 and 2012. Therefore, this begs a logical question of whether the NPLs are a sufficient indicator of a crisis and whether greater resilience of total loan portfolio is achieved through their resolution.

\section{Implementation of Podgorica Approach}

It would be erroneous to expect that the problem of distressed loans is to be resolved by individual banks or that it will resolve by itself. In any case, a more efficient and professional management of this process is needed. It was a serious signal that concrete actions should be taken to solve this problem in the Mon- 
tenegrin banking sector. In order to resolve these problems as soon as possible, financial and monetary authorities of Montenegro with the expert assistance of the World Bank Financial Sector Advisory Centre (FinSAC) Vienna designed a range of measures aimed at reducing non-performing loans in Montenegrin banking sector. This conceptual approach called the "Podgorica approach" aims to achieve greater stability of the banking sector as well as revitalise lending activity to economically viable companies (Fabris \& Žugić 2013, pg. 53-64). The basis for the implementation of this approach is voluntary financial and corporate restructuring, which regulates the conditions of debt restructuring to financial institutions.

After the analysis of financial situation of the borrowers, the creditors should consider the possibility of financial restructuring of debt. The restructuring plan must show whether the creditors have real possibilities for the settlement of their claims, and the borrowers the ability to service their debts regularly.

Financial restructuring should be based on:

1. A well-designed restructuring plan for each individual loan, which should contain:

- financial information about the borrower, its business activities and the guarantor,

- collateral valuation,

- defined appropriate measures of financial restructuring,

- adequate legal documentation that enables changes of deadlines for loan repayment;

2. A realistic assessment of financial performance of the borrower;

3. Determining total debts of the borrower and its sustainability in the restructuring process;

4. An assessment of the exposure of new loan to loss under a restructuring arrangement.

Restructuring arrangement may include one or more financial restructuring measures, such as, for example (Decision on Minimum Standards for Credit risk Management in Banks, 2013):

1. extension of repayment of principal and / or interest;

2. reduction in interest rates on the loans granted;

3. assumption of receivables that the borrower has against third party, on behalf of the full or partial loan repayment;

4. reduction of the amount of debt, principal and interest; 
5. replacement of the existing loan(s) with new loan (loan renewal);

6. purchase of the debtor's receivables;

7. provision of additional collateral from debtors or third parties;

8. debt to equity swap;

9. settlement

In addition to these measures, some incentives in the form of tax incentives for creditors and debtors are envisaged under the Podgorica Approach:

1. exemption from tax on real estate turnover when a bank acquires property in the process of loan collection;

2. exemption from VAT when selling the debtor's assets;

3. exemption from income tax in debt write-off:

- reduction of doubtful debts that cannot be collected for the creditor,

- debt write off - reduction or loss availability of capital,

- debt to equity swap,

- consequences arising from taxes for debtor in connection with arrangements for debt write-off.

Moreover, the Podgorica Approach anticipates the possibility of subsidizing a portion of interest rate on restructured loans by the State.

Corporate restructuring involves changing of some of the structures of a company (assets, capital, management, costs, and organisation) in order to relax and reduce the restrictions and improve the company's performance. Companies with poor performance may (Draganac, 2013):

1. restructure their business through rationalization and reduction of production costs, in order to improve efficiency and profitability;

2. change management structure, including the removal of the existing management;

3. sell assets to ensure cash to pay obligations and, on the other hand, conduct strategic disinvestments of the existing activities or invest in new activities, in order to change the business strategy configuration.

\section{Business restructuring:}

1. A process of causing discontinued and significant changes in the structure (and height) of the engaged resources in the company

2. Division of strategy:

- expansion strategy $\Rightarrow$ it is realised through merger and acquisition transactions; 
- contraction strategy $\Rightarrow$ it is realised through several different disinvestment transactions - elimination or separation of a business part of the company: business line, business unit, sell-off or purchase of a portion of the company by management (MBO)

The expansion strategy involves attracting additional capital, while the contraction strategy affects the inflow of cash or rearrangement of proprietary rights in the company.

The financial and corporate restructuring is planned in two phases under the Podgorica Approach. Loan portfolios of debtors that are classified into the classification categories in the process of credit risk assessment would be restructured in the first phase. Other portfolios that are classified in lower classification categories of credit risk would be resolved in the second phase of debt restructuring. This approach is aimed at strengthening the "active" part of the loan portfolio of Montenegrin banking sector. Plans for resolving "inactive" component of loan portfolio of the banking sector will be prepared when the achievement of the first objective is sufficiently ensured (The WORLD BANK - FinSAC, 2013).

Based on the empirical research, past due loans (B, C and D) showed growth (Figure 3) during the financial crisis. Therefore, the recovery process should also include all past due loans since full effects of the restructuring can be realised in this way. Portfolio from the classification credit risk category "E" was not taken into consideration since it was carried on in the off balance sheet as loss until the end of 2012. Since January 2013, banks are required to transfer receivables classified as E from the off-balance sheet into the balance sheet. In accordance with the new regulation, loans include more balance sheet positions compared to the previous period. The amount of loans for 2013 is shown on net principle (in accordance with the IAS requirements - Bank values balance sheet and off-balance sheet asset items in accordance with the International Accounting Standards and reports them in accordance with the International Financial Reporting Standards), while asset quality indicators are shown on gross principle (in accordance with the established methodology). One of the consequences of changes of the regulations and chart of accounts is the increase in both non-performing loans and all past due loans (Table 2).

Before making NPL resolution plans, which according to the FinSAC proposal include portfolios ( $\mathrm{B}$ and $\mathrm{C}$ ) in the first phase, this document includes portfolios (B, C and D) that will be mapped according to the following components:

1. portfolio that can be returned in the performing status through expected: 
- financial restructuring, and

- measures of corporate restructuring,

2. remaining portfolio will be returned to the status of non-performing loans after failed restructuring,

3. portfolio that should be protected through accelerated activity of the collection and realization of collateral, because the loss of economic viability is inevitable.

The Decision on Minimum Standards for Credit Risk Management requires the banks to adopt NPL resolution strategies. When developing their NPL resolution strategies, banks should take into account the following:

1. an option of the recovery of non-performing loans, which can be applied to non-performing loans for which the bank estimates that can be returned into performing status by sustainable financial restructuring;

2. Option of enforced resolution of non-performing loans, which can be applied to non-performing loans for which a bank estimates that they cannot be returned to the performing status and therefore they are committed to the final collection.

Contrary to the above Decision, this paper recommends banks to adopt a strategy for resolution of all past due loans (B, C, D) taking into account the recovery and resolution measures, and to include also corporate restructuring together with the financial restructuring (MATRIX 1).

\begin{tabular}{|c|c|c|c|c|c|c|}
\hline \multirow{3}{*}{$\begin{array}{l}\text { MATRIX } 1 \\
\text { Activities }\end{array}$} & \multicolumn{6}{|c|}{ Recovery and resolution indicators for past due loans } \\
\hline & \multicolumn{2}{|c|}{ Portfolio "B" } & \multicolumn{2}{|c|}{ Portfolio "C" } & \multicolumn{2}{|c|}{ Portfolio “D” } \\
\hline & TOT & Debt write off & TOT & Debt write off & TOT & Debt write off \\
\hline \multicolumn{7}{|c|}{ RECOVERY MEASURES } \\
\hline Financial restructuring & $* 40 \%$ & & $* 35 \%$ & & $* 25 \%$ & \\
\hline Easy & $30 \%$ & $0 \%$ & $10 \%$ & $0 \%$ & $0 \%$ & $0 \%$ \\
\hline Medium & $10 \%$ & $30 \%$ & $20 \%$ & $30 \%$ & $15 \%$ & $30 \%$ \\
\hline Deep & $0 \%$ & & $5 \%$ & & $10 \%$ & $30 \%$ \\
\hline$\%$ of success after one year & $85 \%$ & & $80 \%$ & & $70 \%$ & \\
\hline Corporate restructuring & ${ }^{*} 10 \%$ & & $* 10 \%$ & & $* 10 \%$ & \\
\hline Easy & $10 \%$ & $20 \%$ & $5 \%$ & $10 \%$ & $0 \%$ & $10 \%$ \\
\hline Medium & $0 \%$ & & $5 \%$ & $40 \%$ & $5 \%$ & $40 \%$ \\
\hline Deep & $0 \%$ & & & & $5 \%$ & \\
\hline$\%$ of success after one year & $90 \%$ & & $85 \%$ & & $75 \%$ & \\
\hline
\end{tabular}




\begin{tabular}{lccc}
\hline & \multicolumn{3}{c}{ RESOLUTION MEASURES } \\
\hline Recovery & $* 50 \%$ & $25 \%$ & $* 15 \%$ \\
\hdashline By themselves & $30 \%$ & $0 \%$ & $0 \%$ \\
\hline Active collection & $20 \%$ & $25 \%$ & $15 \%$ \\
\hline Enforced loan collection & $* 0 \%$ & $* 30 \%$ & $* 50 \%$ \\
\hline
\end{tabular}

Source: The WORLD BANK (FinSAC) and Author

*Free estimate.

Using this approach, banks should define operational objectives related to reducing the level of non-performing loans before the implementation of the financial and corporate restructuring. These objectives must establish deadlines for the implementation of certain activities in the process of resolution of past due loans, and in particular:

1. deadlines when the loans, which have acquired the status of non-performing loans during the year, will be arranged in categories of loans to be subject to recovery or a measure of enforced collection;

2. deadlines when some of the established measures for financial restructuring and corporate restructuring will be determined for loans opted for the recovery;

3. deadlines in which the bank will enter into a restructuring agreement or cancel the restructuring;

4. deadlines in which recovery indicators will be obtained. They imply the percentage of successfulness of the recovery of loans in relation to total concluded restructuring agreements, whereby a successful restructuring agreement includes:

- restructuring agreement based on a financial restructuring plan accepted by the bank and the borrower,

- restructuring agreement based on a corporate reorganization plan if the borrower fully meets its obligations in accordance with the adopted reorganization plan;

5. deadlines when appropriate measures (court proceedings, out-of-court settlement, sale of receivables, realisation of collateral, and the like) will be taken for loans under the enforced resolution;

In relation to the mapping done by FinSAC for four selected banks, the quantitative assessment of the credit risk in this paper is based on data on the aggregate level of the entire banking system of Montenegro for 2012 (MATRIX 2). 


\begin{tabular}{|c|c|c|c|c|c|}
\hline \multirow{2}{*}{$\begin{array}{c}\text { MATRIX } 2 \\
\text { (in thousands } € \text { ) }\end{array}$} & \multicolumn{5}{|c|}{ NPL management } \\
\hline & $\begin{array}{c}\text { Portfolio } \\
\text { "B" }\end{array}$ & $\begin{array}{c}\text { Portfolio } \\
\text { "C" }\end{array}$ & $\begin{array}{c}\text { Portfolio } \\
\text { "D" }\end{array}$ & Total & $\%$ \\
\hline Original amount & 226,180 & 157,830 & 59,890 & 443,900 & $100 \%$ \\
\hline \multicolumn{6}{|c|}{ RESULTS OF THE RECOVERY MEASURES } \\
\hline Return into "A" & 210,350 & 97,060 & 23,950 & 331,370 & $75 \%$ \\
\hline Recovery & 113,090 & 39,460 & 8,980 & & \\
\hline Financial restructuring & 76,900 & 44,190 & 10,480 & & \\
\hline Corporate restructuring & 20,360 & 13,420 & 4,490 & & \\
\hline Transition into " $\mathrm{E}$ " & 11,300 & 13,420 & 5,690 & 30,410 & \\
\hline Write off after financial restructuring & 6,780 & 9,470 & 4,490 & & \\
\hline Write off after corporate restructuring & 4,520 & 3,950 & 1,200 & & \\
\hline \multicolumn{6}{|c|}{ RESULTS OF THE REOLUTION MEASURES } \\
\hline Transition and remaining into " $\mathrm{D}$ " & 15,830 & 60,770 & 35,930 & 112,530 & $25 \%$ \\
\hline Enforced loan collection & 0,000 & 47,350 & 29,940 & & \\
\hline Failed financial restructuring & 13,570 & 11,050 & 4,490 & & \\
\hline Failed corporate restructuring & 2,260 & 2,370 & 1,500 & & \\
\hline \multicolumn{6}{|c|}{ RECOVERY INDICATORS } \\
\hline Return into " $\mathrm{A}$ "/Total & $93 \%$ & $62 \%$ & $40 \%$ & & \\
\hline Transition and remaining into "D"/ Total & $7 \%$ & $38 \%$ & $60 \%$ & & \\
\hline (Loss) Transition into "E"/ Total & $5 \%$ & $8 \%$ & $9 \%$ & & \\
\hline
\end{tabular}

Source: The WORLD BANK (Fin SAC) and Author

\section{RESULTS OF THE RECOVERY MEASURES}

Return into "A"

Recovery:

Financial restructuring:

Corporate restructuring:
Portfolio "B" 210,350 $226,185 \times 50 \%=113,090$ $226,180 \times 40 \% \times 85 \%=76,900$ $226,180 \times 10 \% \times 90 \%=20,360$

Return into "A"

Portfolio "C"

Recovery: 97,060

Financial restructuring: $157,830 \times 25 \%=39,460$

Corporate restructuring: $157,830 \times 35 \% \times 80 \%=44,190$ $157,830 \times 10 \% \times 85 \%=13,410$ 
Portfolio "D"

Return into "A"

23,950

Recovery:

$59,890 \times 15 \%=8,980$

Financial restructuring:

$59,890 \times 25 \% \times 70 \%=10,480$

Corporate restructuring:

$59,890 \times 10 \% \times 75 \%=4,490$

Portfolio "B"

Transition into "E" 11,300

Write off after financial restructuring:

$(226,180 \times 0 \% \times 30 \%)+(226,180 \times 30 \% \times 10 \%)=6,780$

Write off after corporate restructuring:

$226,180 \times 20 \% \times 10 \%=4,520$

Portfolio "C"

Transition into "E" 13,420

Write off after financial restructuring:

$(157,830 \times 0 \% \times 10 \%)+(157,830 \times 30 \% \times 20 \%)=9,470$

Write off after corporate restructuring:

$(157,830 \times 10 \% \times 5 \%)+(157,830 \times 40 \%$ x $5 \%)=3,950$

Portfolio "D"

Transition into "E" 5,690

Write off after financial restructuring:

$(59,890 \times 0 \%$ x $0 \%)+(59,890 \times 30 \%$ x $15 \%)+(59,890 \times 30 \%$ x $10 \%)=4,490$ Write off after corporate restructuring:

$(59,890 \times 10 \%$ x $0 \%)+(59,890 \times 40 \%$ x $5 \%)=1,200$

\section{RESULTS OF THE RESOLUTION MEASURES}

Transition and remaining into " $\mathrm{D}$ "

Portfolio "B"

Enforced loan collection: 15,830

Failed financial restructuring: $226,180 \times 0 \%=0$

Failed corporate restructuring: $226,180 \times 40 \% \times 15 \%=13,570$ $226,180 \times 10 \% \times 15 \%=2,260$

Transition and remaining into " $\mathrm{D}$ "

Portfolio "C"

Enforced loan collection: 60,770

Failed financial restructuring: $157,830 \times 30 \%=47,350$

Failed corporate restructuring: $157,830 \times 35 \% \times 20 \%=11,050$ $157,830 \times 10 \% \times 15 \%=2,370$ 


\begin{tabular}{lr} 
Transition and remaining into “D” & $\begin{array}{r}\text { Portfolio ”D" } \\
35,930\end{array}$ \\
\hline Enforced loan collection: & $59,890 \times 50 \%=29,940$ \\
Failed financial restructuring: & $59,890 \times 25 \%$ x $30 \%=4,490$ \\
Failed corporate restructuring: & $59.890 \times 10 \%$ x $25 \%=1,500$
\end{tabular}

\section{Implementation of the Process}

As a result of this approach, adoption of the Law (Lex Specialis) is planned. This law will re-regulate relationships between debtor and creditor (the bank) as well as other interested creditors. The evaluation of the scope and characteristics of past due loans that could return to the performing status through the voluntary restructuring process is very important for the adoption of appropriate legislative solution.

The key features of the process set out in this law are that it is voluntary and based on the London Club and the INSOL principles (International Federation of Insolvency Professionals). The voluntary nature of the process is based on the consent between creditors and debtors where at least one bank is involved. It would be desirable if other creditors participated as well. This is a process that primarily deals with the debtor-creditor relationship involving creditors and companies. This process suggests the inclusion of the household sector in the area of mortgage loans.

The organisational structure of the process should include the supervisory body the Centre for Mediation under the leadership of the Association of Montenegrin Banks and /or the Central Bank of Montenegro (CBCG). The Centre should do the following (Josef \& Jiri 2014, pg. 2-21):

1. provide technical support for the implementation of restructuring plans;

2. coordinate participation of professionals engaged in the Arbitration Council;

3. give professional and logistic support in conducting meetings with multi creditors;

4. establish standard documentation for the implementation of the restructuring process;

5. provide information to potential investors for the purpose of mobilising new sources of funding;

6. establish database of participants in the restructuring process;

7. produce annual reports on the results achieved. 
The Arbitration Council should be established within the Centre, which would be appointed by the Association of Banks and /or the CBCG. The Arbitration Council would decide on the acceptance or denial of the model of debt restructuring for a particular loan. If more than $75 \%$ of creditors (based on their share in total value) accepts model of debt restructuring, it becomes binding also for other creditors and the Arbitration Council is not required to decide about it. If the model is accepted by more than $50 \%$ and less than $75 \%$ of the creditors, the process of arbitration is included. The creditors will establish the Creditors Committee for each model of debt restructuring. This committee will be represented by the creditor with the highest share. Other creditors will be included on a caseby-case basis, as needed.

\section{Scheme 1: The institutional structure of Podgorica process}

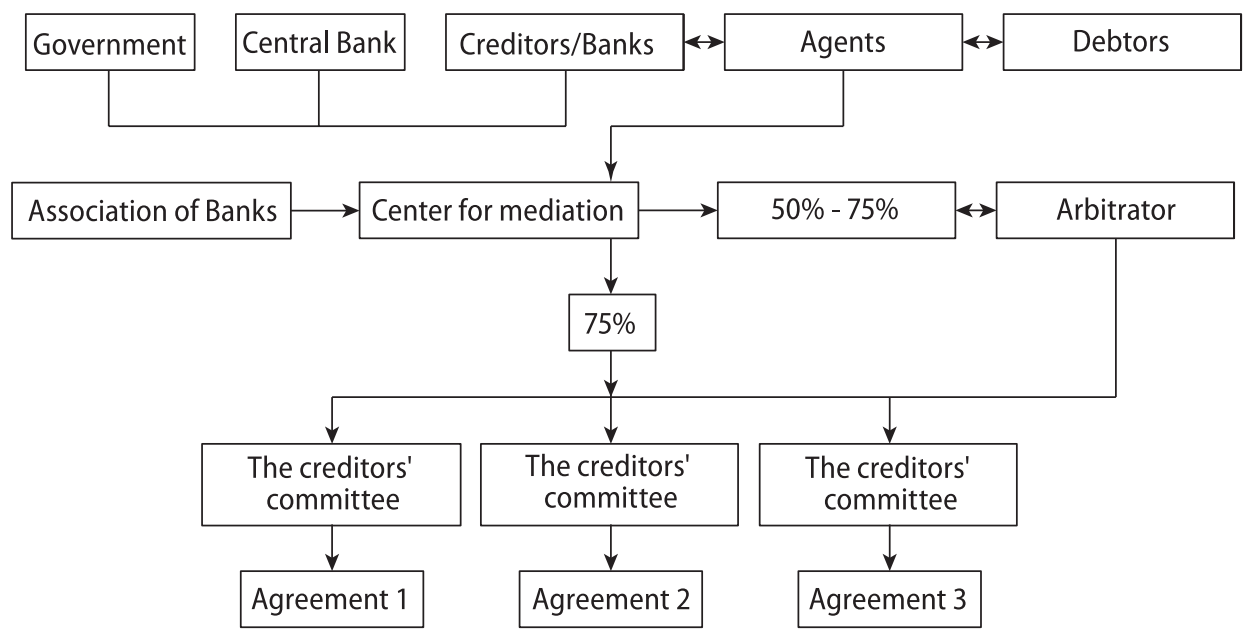

Source: author

Interim prohibition - standstill arrangement: a reasonable standstill period of 90 days would be ensured for each restructuring model. During this period, all obligations of company would remain dormant in the sense that no bankruptcy proceedings could be initiated, the bank would not initiate enforced collection of collateral, and the state would not initiate enforced collection of taxes, contributions and other obligations of the company.

Companies that enter into the process of voluntary debt restructuring must be sustainable. Instability of the economic sector of Montenegro poses significant challenges for banks that are trying to comprehend the business of compa- 
nies. The analyses from various sources indicate that companies in Montenegro showed many weaknesses during the crisis. Bearing these facts in mind, it is no wonder that banks are having problems in assessing corporate distresses and slow resolution of their problems. In fact, the only readily available measure of corporate distress is loss portfolio or the extent of problem loans in the banking system. Therefore, it is necessary to draw up a list of financially responsible companies which have experienced unexpected periods of poor liquidity flows. There are two options how to get to this list. The first option is to do it through the audit process, and the second rests on the banks alone to do so. Companies that find themselves on this list are to be included in the restructuring process.

\section{Concluding Remarks}

Montenegro's economy is a small-scale economy, which is dominated by small and micro companies, with very few medium-sized enterprises and large corporations almost do not exist (until recently it was KAP). Under the influence of the current financial crisis, Montenegrin economy has exhibited exceptionally high vulnerability and non-resilience to adverse economic developments that significantly jeopardized stability and increased financial borrowings of companies. Therefore, logical question is whether it is necessary to react in short- or long-term and implement the process of voluntary debt restructuring of companies in two phases. Logically, it is not necessary to perform any segmentation or implement the processes in two or more phases as valuable time would be lost and the realisation effects of certain activities such as voluntary debt restructuring would be small.

Recovery indicators in MATRIX 2 show that good results are achieved through restructuring even in portfolio " $\mathrm{D}$ ". Thus, resolution of debt for this portfolio should be included simultaneously with the resolution of debt for the portfolios " $\mathrm{B}$ " and " $\mathrm{C}$ ". Based on the empirical research, it can be concluded that better effects of the restructuring are achieved by resolving simultaneously all past due loans. The implementation of the Podgorica Approach created the preconditions for the resolution of debts from the loan portfolio "E" (loss). The fact that banks have been obliged to transfer receivables of this credit risk category from the offbalance sheet to the balance sheet as of 2013 (in accordance with the IAS requirements) supports the aforesaid.

In addition to the financial and corporate debt restructuring, it would be preferable to include measures of business restructuring. In particular those business restructuring measures related to the implementation of the contraction strategy, which is implemented through multiple transactions of disinvestments. This 
would imply the separation of a healthy part of the company and its recovery or purchase by the management.

No approach has been developed in Montenegrin financial market until recently, which would quickly resolve problems arising from the past due loans growth. Although Montenegrin laws regulating the collection of non-performing loans are contemporary, some weaknesses in their particular implementation are noted. For example, the Bankruptcy Law did not envisage a streamlined procedure by which the court would approve an accelerated confirmation of the restructuring plan approved by majority creditors. Furthermore, no possibility of the suspension of proceedings pending the restructuring process has been provided or the protection against transaction risk, and the transactions concluded in good faith may be challenged in the course of bankruptcy.

The legal framework and the institutions connected with the enforced collection of loans, debt restructuring and reorganization and liquidation of companies could be further strengthened through: appointment and fast start of work of bailiffs, which has been done in the meantime; review and amendments to tax regulations to eliminate the existing tax disincentives and to introduce tax incentives - perhaps for a limited period - for measures that implement debt restructuring and resolution of problem loans; the adoption of a series of principles and guidelines that would be used in practice as the code of conduct for the participants in the process of finding solutions for problem loans, as those set out in the "London Approach" and the INSOL principles; and establishment of a system for alternative settlement of disputes to be applied to conflicts that may arise among creditors in the context of bargaining solutions for non-performing loans.

The initial assumption of the Podgroica approach is that financially responsible companies should be given a chance to execute the consolidation of business in order to stabilise their revenues. Everyone could benefit in long-term from the successful implementation of this approach: banks which, instead of the write-off of receivables, would be able to collect a significant portion of the debt; the State would get stable companies that would be able to settle their obligations; the Central Bank of Montenegro would obtain a stable financial system and reduced a danger of systemic risk; and companies would avoid the consequences that could occur in case of bankruptcy.

The law on insolvency of natural persons should be adopted to resolve permanently total households' debt, and responsible individuals would be given the opportunity to consolidate their financial situation. Advisory centres for debt should be considered where the debtors will be educated to contact their banks in time to come up with solutions for their repayment problems. 


\section{REFERENCES}

1. Decision on Minimum Standards for Credit Risk Management in Banks (OGM 22/12 of 23.04.2012, 55/12 of 02.11.2012 and 57/13 of 16.12.2013)

2. Demirgüç -Kunt, E., Gupta, D. and P. (2000). „Inside the Crisis: An Empirical Analysis of banking Systems in Distress". Washington, DC: World Bank. Policy Research Working Paper No. 156.

3. Diwan, I. and Rodrik, D. (1992). "Debt Reduction, Adjustment Lending, and Burden Sharing”, NBER Working Paper, No. 4007.

4. Draganac, D. (2013). „Pojam i oblici korporativnog upravljanja”. Preuzeto sa: http://www.ekof.bgac.rs

5. Fabris, N. i Žugić, R. (2013). Koordinacija monetarne i fiskalne politike u Crnoj Gori, Ekonomske ideje i praksa br.8, str. 53-64.

6. Goldstein, M., and Weatherstone, D. (2001). "Implications of Early Warning Models of Crisis". Paper prepared for KDIC International Financial Symposium on "The Financial Crisis and Beyond". Seoul, Korea, December.

7. Josef, R. end Jiri, J. (2014). Corpotate \& SMS Risk Competencies. ABCADASTRA BUSINESS CONSULTING, Version: 1,0

8. Passamonti, L. (2013). Mapiranje oporavka nekvalitetnih kredita u Crnoj Gori - Projektni zadatak The WORLD BANK (Fin SAC), Module: 4.

9. Zaini Abd Karim, M., Chan Sok, -Gee, C. and Sallahudin, H. (2010). "Bank Efficiency and Non-performing Loans: Evidence from Malaysia and Singapore", Prague Economic papers, 2. 